\title{
Publisher Correction: Identification of a peptide recognizing cerebrovascular changes in mouse models of Alzheimer's disease
}

\author{
Aman P. Mann¹, Pablo Scodeller ${ }^{1,2}$, Sazid Hussain ${ }^{1,3}$, Gary B. Braun¹, Tarmo Mölder², Kadri Toome ${ }^{2}$, \\ Rajesh Ambasudhan ${ }^{4}$, Tambet Teesalu², Stuart A. Lipton ${ }^{4,5}$ \& Erkki Ruoslahti, 6
}

Correction to: Nature Communications https://doi.org/10.1038/s41467-017-01096-0, published online 10 November 2017.

The original version of the Supplementary Information associated with this Article inadvertently omitted Supplementary Table 1. The HTML has now been updated to include a corrected version of the Supplementary Information.

Published online: 09 March 2018

\begin{abstract}
(c) (i) Open Access This article is licensed under a Creative Commons Attribution 4.0 International License, which permits use, sharing, adaptation, distribution and reproduction in any medium or format, as long as you give appropriate credit to the original author(s) and the source, provide a link to the Creative Commons license, and indicate if changes were made. The images or other third party material in this article are included in the article's Creative Commons license, unless indicated otherwise in a credit line to the material. If material is not included in the article's Creative Commons license and your intended use is not permitted by statutory regulation or exceeds the permitted use, you will need to obtain permission directly from the copyright holder. To view a copy of this license, visit http://creativecommons.org/licenses/by/4.0/.
\end{abstract}

(c) The Author(s) 2018

\footnotetext{
${ }^{1}$ Cancer Research Center, Sanford Burnham Prebys Medical Discovery Institute, La Jolla, CA 92037, USA. ${ }^{2}$ Laboratory of Cancer Biology, Institute of Biomedicine and Translational Medicine, University of Tartu, Tartu 50411, Estonia. ${ }^{3}$ AivoCode Inc, La Jolla, CA 92037, USA. ${ }^{4}$ Neurodegenerative Disease Center, Scintillon Institute, San Diego, CA 92121, USA. ${ }^{5}$ Department of Neurosciences, University of California, San Diego, School of Medicine, La Jolla, CA 92093, USA. ${ }^{6}$ Center for Nanomedicine and Department of Cell, Molecular and Developmental Biology, University of California, Santa Barbara, Santa Barbara, CA 93106, USA. These authors contributed equally: Aman P. Mann and Pablo Scodeller. Correspondence and requests for materials should be addressed to E.R. (email: ruoslahti@sbpdiscovery.org)
} 